\title{
RNA Extraction from the Yeast Candida parapsilosis Sensu Stricto Using Two Commercial Methods Based on Purification by Silica Columns
}

\author{
Rodríguez $\mathrm{ML}^{1,2^{*}}$, Rosa $\mathrm{AC}^{3}$ and Jewtuchowicz VM${ }^{1,4}$ \\ ${ }^{1}$ Department of Microbiology, Parasitology and Immunology, University of Buenos Aires, Argentina \\ ${ }^{2}$ Department of Semiology and Diagnostic Clinic, School of Dentistry, University of Cuenca, Cuenca City, Ecuador \\ ${ }^{3}$ Department of Microbiology and Parasitology, University of Buenos Aires, Buenos Aires, Argentina \\ ${ }^{4}$ HIGA Gandulfo Hospital, Laboratory Service, Province of Buenos Aires, Argentina
}

\begin{abstract}
Good quality RNA needs to be obtained in order to study gene expression. Different RNA extraction methods have been described, but RNA quality and yield may vary among the different techniques and biological study species. To date, there is no standardized method for extraction and purification of RNA from Candida genus yeasts. The few available papers on the subject apply mainly to filamentous fungi and have produced poor results for extraction techniques based on manual or in-house IVD methods. The aim of this study was therefore to compare two commercial RNA extraction and purification systems using silica columns (Qiagen and Zymo Research) with Candida parapsilosis sensu stricto as model organism. This yeast has been identified in recent papers as the second most frequently isolated Candida species in the oral cavity. In the past decade, it has been the object of increasing medical interest because it is one of the main causes of candidemia in both adults and preterm neonates. In view of this background, we consider the study of Candida parapsilosis sensu stricto transcriptome and its variations according to environmental changes to be a priority. In this experimental study, 19 fungal isolates were processed using Qiagen and 17 isolates using Zymo Research. The results suggest that Qiagen lysis buffer RLT is essential for obtaining better quality RNA product.
\end{abstract}

Keywords: RNA extraction; RNA purification; Candida parapsilosis sensu stricto; Silica columns

\section{Introduction}

Developments in molecular biology have enabled molecular techniques to be used in mycological studies, thereby promoting more precise diagnoses in shorter times and above all, enabling culturable fungi with low abundance as well as non-culturable fungi to be identified through analysis of their genetic material. Moreover, techniques for analysis of gene expression have enabled the study of gene function, providing understanding of interactions between the host and its mycobiome, and the response of each fungal species to different environmental conditions.

Good quality RNA is needed to study gene expression. It is therefore important to use the best possible RNA extraction method, since any contaminants such as RNases, proteins, polysaccharides and genomic DNA may affect RNA quality and reduce the efficiency of its amplification. RNA extraction is particularly critical for fungal cells because their cell wall characteristics differ according to genus, and the processes must be optimized for each particular case. In addition, RNA is highly labile and less stable than DNA [1].

Different methods are currently available for disruption and homogenization of tissues with liquid nitrogen, sand, beads or mycelium lyophilization for filamentous fungi $[2,3]$. Techniques based on enzymatic disruption of the wall by zymolyase or lyticase are the most frequently used options for yeasts [4]. However, regardless of the method used, there is always a latent risk of rehydration of samples and activation of RNases. To date, different processes have been reported for RNA extraction, including, among others, the use of phenolic compounds, triazoles, sodium dodecyl sulfate (SDS), lithium chloride, detergents such as hexa decyltrimethyl ammonium bromide (CTAB), and increasingly frequently, commercial extraction kits [5,6]. Nevertheless, the quality and yield of the extracted RNA may vary according to the methodology applied and the biological study species [7].
Candida parapsilosis sensu stricto is part of the human mycobiome, and according to two studies on oral mycobiome, is the second most frequently isolated Candida species in the oral cavity $[8,9]$. In the past decade, it has been the object of increasing medical interest because it is one of the main causes of candidemia, especially in Latin America, Europe and Asia; in both adults and preterm neonates [10-14]. Considering this background, it is a priority to study the transcriptome of this Candida species and its variations in response to environmental changes.

There is no standardized methodology to date for extraction and purification of RNA from yeasts of the genus Candida. The few papers on the subject apply mainly to filamentous fungi, and have provided poor results for extraction techniques based on manual or in-house IVD techniques. The aim of this study was therefore to compare two commercial systems, Qiagen and Zymo Research, for extraction and purification of RNA with silica columns. The main differences between the two systems are the homogenization system used for cell suspension and cost.

The Qiagen system was selected for its lysis buffer RLT, which has high concentrations of guanidine isothiocyanate and lacks phenol in its composition. As far as we know, there is no other system on the market with similar composition. For extraction and purification of RNA, the

*Corresponding author: Rodríguez ML, Department of Microbiology, Parasitology and Immunology, University of Buenos Aires, Argentina, Tel: 1168186883; E-mail: malourdes84@hotmail.com

Received May 18, 2018; Accepted July 02, 2018; Published July 09, 2018

Citation: Rodríguez ML, Rosa AC, Jewtuchowicz VM (2018) RNA Extraction from the Yeast Candida parapsilosis Sensu Stricto Using Two Commercial Methods Based on Purification by Silica Columns J Microb Biochem Technol 10: 96-105. doi: 10.4172/1948-5948.1000401

Copyright: @ 2018 Rodríguez ML, et al. This is an open-access article distributed under the terms of the Creative Commons Attribution License, which permits unrestricted use, distribution, and reproduction in any medium, provided the original author and source are credited. 
Citation: Rodríguez ML, Rosa AC, Jewtuchowicz VM (2018) RNA Extraction from the Yeast Candida parapsilosis Sensu Stricto Using Two Commercial Methods Based on Purification by Silica Columns J Microb Biochem Technol 10: 96-105. doi: 10.4172/1948-5948.1000401

Zymo-research system was selected due to its lysis buffer based on a combination of phenol and guanidine, with the commercial name of Tri-reagent, which is equivalent to trizol. These are two ideal systems to be compared in terms of their efficiency in obtaining good quantity and quality of RNA.

\section{Material and Methods}

\section{Experimental design}

A retrospective, cross-sectional, comparative basic research study was designed to compare two commercial systems for extraction and purification of RNA with silica columns regarding their ability to provide more and better quality biomolecules from the fungal cell biomass of the yeast Candida parapsilosis sensu stricto. A collection of 36 isolates was used, which had been characterized as Candida parapsilosis sensu stricto in a previous study using molecular methods. The strains were assigned randomly for processing with the Qiagen system ( $n=19)$ or Zymo Research system $(n=17)$.

\section{Ethical statement}

Because the study uses oral fungal isolates derived from patients, the present research was treated by the ethics committee of the Faculty of Odontology, University of Buenos Aires (UBA), with file number 0048223/2016, and approved under the number 012/2016 CETICAFOUBA.

\section{Fungal isolation and preservation}

The Candida parapsilosis sensu stricto yeast isolates were obtained from the yeast collection at the Mycology Center of the Buenos Aires University School of Medicine. The fungus was previously selected on CHROMagar Candida (Becton-Dickinson) differential medium as Candida parapsilosis complex. This was followed by microscopic study on milk-Tween 80 agar and automated Vitek2 system. The species was confirmed by endpoint PCR using specific primers that join to the region ITS1-5.8SrRNA-ITS2, enabling identification of this particular species. Each strain was kept for short periods on Sabouraud agar at $4^{\circ} \mathrm{C}$, and preserved for long periods in glycerol at $-70^{\circ} \mathrm{C}$.

\section{Culture media}

Several culture media were used, beginning with differential chromogenic (CHROMagar Candida) for $24 \mathrm{~h}$ at $37^{\circ} \mathrm{C}$ for initial selection. This was followed by Sabouraud medium for $24 \mathrm{~h}$ at $28^{\circ} \mathrm{C}$ to obtain a subculture and for strain maintenance. Finally, it was placed in YPD broth (yeast extract-peptone-dextrose) for $18 \mathrm{~h}$ at $37^{\circ} \mathrm{C}$ to obtain a more pure and enriched culture in exponential phase.

\section{Sample processing and preparation of spheroplast suspension}

To prepare spheroplasts, $20 \mathrm{ml}$ of the culture in exponential phase in YPD broth was pelleted by centrifuging at room temperature at 3000 $\mathrm{rpm}$ for $5 \mathrm{~min}$. The pellet was re-suspended in $1 \mathrm{~mL}$ cold sorbitol, and the suspension was diluted with sorbitol at ratios of 1:2 and 1:3. The cell density in these dilutions was measured in a spectrophotometer in order to select the concentration that would provide highest RNA yield. The suspension obtained was pelleted twice in refrigerated micro centrifuge at $1000 \mathrm{x} g$ for $5 \mathrm{~min}$ at $4^{\circ} \mathrm{C}$.

The pellet obtained from the second rinse was re-suspended in $100 \mathrm{uL}$ of spheroplast-forming solution (sorbitol+EDTA+betamercaptoethanol+ultra-pure nuclease-free water+1.43 $\mathrm{mg} / \mathrm{mL}$ zymolase) and incubated in a laboratory water bath at $37^{\circ} \mathrm{C}$ for $2 \mathrm{~h}$. Spheroplasts were verified by smear slides stained with toluidine blue and viewed under optical microscope (o.m) (Figures 1 and 2).
This step can be followed immediately by extraction and passage through the column, or the process may be deferred and the spheroplasts kept in a freezer at $-20^{\circ} \mathrm{C}$.

\section{RNA extraction and purification using RNeasy Mini Kit system (Qiagen) + DNase I}

Manufacturer's instructions were followed (Supplementary File 1). It should be noted that this system homogenizes the initial sample (spheroplast suspension) with guanidine isothiocyanate at high concentrations.

The treatment with DNase I (Qiagen brand) is subsequent to the addition of ethanol and prior to the rinses with the respective buffers. Manufacturer's instructions were followed.

The RNA obtained was re-suspended in $30 \mu \mathrm{L}$ of nuclease-free water (provided in the kit), and passed twice through the column.

\section{Extraction and purification of RNA using the Zymo- Research+DNase I system}

Manufacturer's instructions were followed (Supplementary

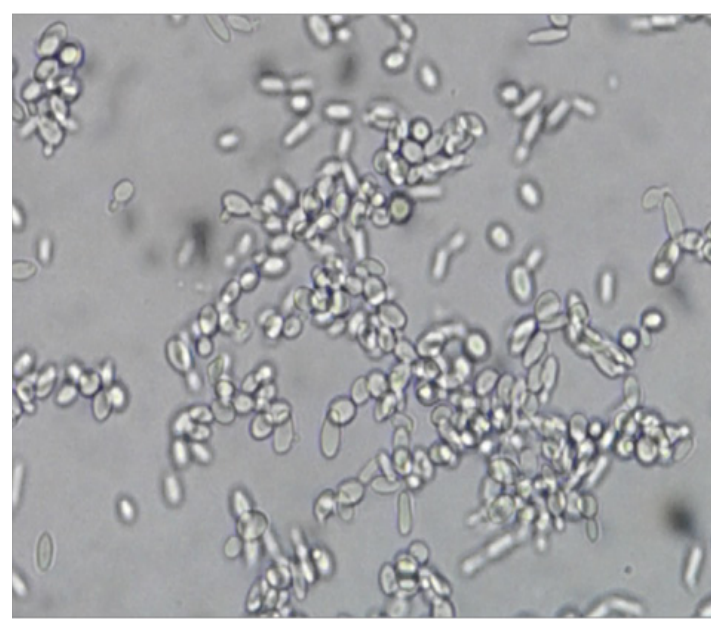

Figure 1: Yeasts with preserved cell wall, prior to the action of zymolase. (Unstained sample, 40X o.m.).

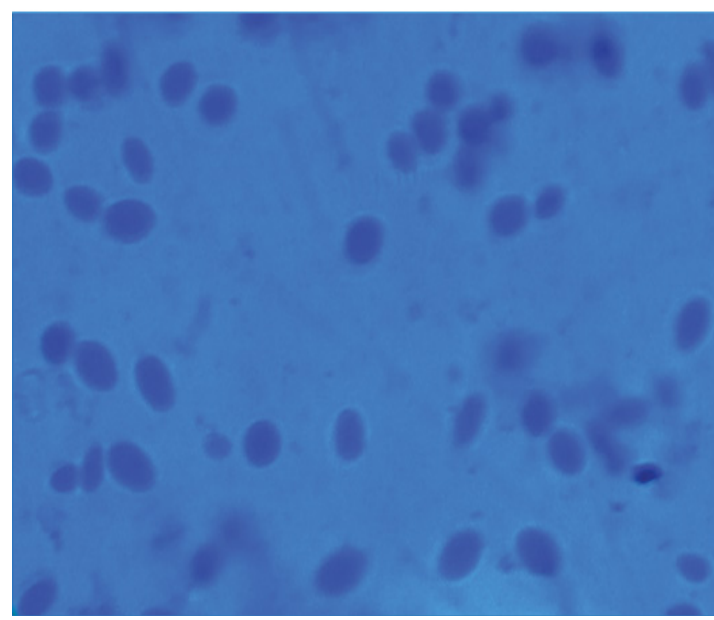

Figure 2: Yeast with altered cell wall, 2 hours after the action of zymolase. (Sample stained with toluidine blue, $40 \mathrm{X}$ o.m.) 
File 2). It should be noted that this system homogenizes the initial sample (spheroplast suspension) with a compound called Tri-reagent (phenol+guanidine isothiocyanate).

The treatment with DNase I (provided in the Zymo Research kit) is after adding ethanol and prior to rinses with the respective buffers. Manufacturer's instructions were followed.

The RNA obtained was re-suspended in $30 \mu \mathrm{L}$ of nuclease-free water (provided in the kit), and passed twice through the column.

\section{Analysis of yield, purity and integrity of RNA}

The RNA solutions obtained were quantified using a Multiskan GO 10040/1510-02746C (Thermofisher) spectrophotometer, with wavelength 260 , and the concentration in $\mathrm{ng} / \mu \mathrm{L}$ was obtained by means of the following formula: Abs $260^{\star} 40^{*}(\mathbf{1 0} / \mathbf{0 , 5 1})$. RNA purity was determined for each sample by means of the absorbance ratio A260/280, which measures contamination by proteins, and A260/230, which measures contamination by carbohydrates, phenols and salts.

The results for purity and yield were processed and analyzed in Microsoft Excel 2010 and InfoStat 2016 statistical package, using mean, standard deviation and coefficient of variation. A 95\% confidence interval was used and statistical significance was determined by bilateral Mann Whitney test because the data do not follow normal distribution. The data were represented in bar charts with error bars.

In addition, RNA integrity and contamination by genomic DNA were checked and recorded by direct visualization in $2 \%$ agarose gel stained with ethidium bromide. The gel was run at 93 volts for $1 \mathrm{~h}$ and viewed in a UV trans illuminator.

RNA was preserved at $-70^{\circ} \mathrm{C}$,

\section{Preparation of copy DNA (cDNA)}

BioRad reverse transcriptase (iScript ${ }^{\text {mis }}$ cDNA Synthesis Kit, 100 x 20 $\mu \mathrm{l}$ rxns \#1708891), which is was used to transcribe RNA to cDNA. The iScript is genetically engineered MMLV.

The kit provides $400 \mu \mathrm{L}$ of the $5 \mathrm{x}$ reaction mix (buffer+primers+stabilizers); $100 \mathrm{~L}$ of iScript reverse transcriptase; and $1.5 \mathrm{~mL}$ of nuclease-free water.

The reaction was prepared in a total volume of $20 \mu \mathrm{L}$, constituted of $4 \mu \mathrm{L}$ reaction mix plus $1 \mu \mathrm{L}$ enzyme, plus nuclease-free water as required, and RNA in an amount adjustable to a concentration of $1 \mu \mathrm{g}$ in the $20 \mu \mathrm{L}$ reaction volume (Table 1 ).

\section{Cycling conditions were the following}

Design of primers for amplification of the ITS region: With the aim of evaluating the quality of the RNA obtained, a set of primers was designed based on the ITS (internal transcribed spacer) region, which is a sequence that transcribes without modifications and is present in all fungi, and used regularly for typing and genotyping (Figure 3 ). The sequence of the ITS region of a reference strain of Candida parapsilosis sensu stricto (ATCC 22019) was used, and Primer Blast software used to design the primers with parameters preset by the program. To determine specificity, a search was done in RefSeq genome databases for the organism Candida.

The sequences obtained were the following:

ITS 1 forward: TCCGTAGGTGAACCTGCGG

ITS 4 reverse: TCTTTTCCTCCGCTTATTGATATG
The primers were validated in silico and experimentally. The PrimerBlast algorithm enabled primer design and showed specificity with the ITS1-ITS2 region of ribosomal DNA corresponding to Candida orthopsilosis (Figure 4), which is transcribed without modifications.

Experimental validation of primers was done by RT-PCR, using the cDNA of the set of samples selected; and sequencing of the purified amplification product plus bioinformatic analysis. The aim of the RT-PCR is to obtain amplicons of the expected size (517pb). Sanger sequencing of the PCR product plus bioinformatic analysis (https:// blast.ncbi.nlm.nih.gov/Blast.cgi) were used to find specificity, i.e., homology with region ITS 1-ITS2 of ribosomal DNA.

\section{Conditions and performance of the RT-PCR}

To do the RT-PCR, the RNA obtained was transcribed to cDNA (copy DNA) with the BioRad kit (iScript cDNA Synthesis kit $100 \mathrm{x}$ $20 \mu \mathrm{L}$ reactions), according to the manufacturer's instructions, based on $1 \mu \mathrm{g}$ RNA altogether. Using the cDNA obtained, the RT-PCR was performed under the following conditions: $8 \mathrm{cDNA}$ samples processed by Qiagen and $8 \mathrm{cDNA}$ samples processed with the Zymo-Research system were selected at random, to be subjected to RT-PCR of the region ITS1-ITS2, using the pair of primers described above. The PCR was performed with 3 controls: a positive control based on genomic DNA from a reference strain for C. parapsilosis sensu stricto ATCC 22019; a negative control based on replacing cDNA by water, and a detection limit control based on cDNA diluted 1:10. The unknown cDNAs were diluted 3:10 (Figure 5).

Table 2 shows concentration and volume for each component in the RT-PCR reaction.

The PCR cycles were carried out in the Mini CyclerTM thermocycler, MJ Research INC, with the following protocol:

\section{Statistic analysis}

The data on concentration and purity, obtained by each commercial system, were processed and analyzed in the Microsoft Excel 2010 programs, and the statistical package Info Stat 2017. For the descriptive analysis of the variables, the average, standard deviation, median, first and third quartiles statistics were used; in addition to bar chart with standard error, and dot density chart for the comparative study.

The normality of the data was established by the Q-Q-plot test and the Shapiro Wilks test. On the other hand, the homogeneity of

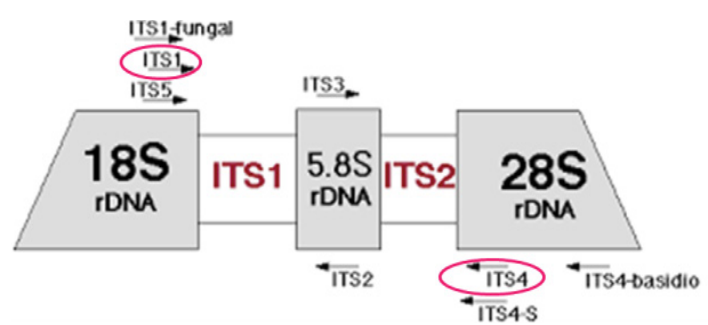

Figure 3: The ITS1 and ITS4 primers allow to raise a region of the fungal ribosomal RNA of $517 \mathrm{bp}$

Reaction protocol Incubate the complete reaction mix in a thermal cycler using the following protocol:

\begin{tabular}{|c|c|}
\hline Priming & $5 \mathrm{~min}$ at $25^{\circ} \mathrm{C}$ \\
\hline Reverse transcription & $20 \mathrm{~min}$ at $46^{\circ} \mathrm{C}$ \\
\hline RT inactivation & $1 \mathrm{~min}$ at $95^{\circ} \mathrm{C}$ \\
\hline Optional step & Hold at $4^{\circ} \mathrm{C}$ \\
\hline
\end{tabular}

Table 1: Thermocycling conditions for retrotranscription protocol. 


\section{Detailed primer reports}

\begin{tabular}{lllllll} 
Primer pair 1 & \multicolumn{1}{l}{} \\
& Sequence $\left(5^{\prime}>>3^{\prime}\right)$ & Length & Tm & GC\% & Self complementarity & Self 3' complementarity \\
Forward primer & TCCGTAGGTGACCTGCGG & 19 & 61.64 & 63.16 & 10.00 & 10.00 \\
Reverse primer & TCTTTTCCTCCGCTTATTGATATG & 24 & 56.89 & 37.50 & 4.00 & 4.00
\end{tabular}

Products on target templates

$>$ NC 018301.1 Candida orthopsilosis Co 90-125, chromosome 7 draft sequence

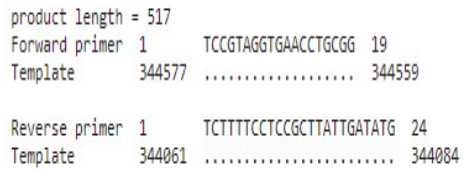

Figure 4: Characteristics, sequence and specificity of the primers used for RT-PCR.

\section{A 5-minute cycle at 95 - C \\ 30 cycles, each with 3 stages of: \\ 20 seconds at $95^{\circ} \mathrm{C} / / 15$ seconds at $55^{\circ} \mathrm{C} / / 65$ seconds. at $722^{\circ} \mathrm{C}$ \\ Finallx a cycle of 5 min at $72 \circ \mathrm{C}$}

Figure 5: Amplification conditions with ITS1-ITS4 primers.

\begin{tabular}{|c|c|c|c|}
\hline Components & Stock concentration & Final concentration & $\begin{array}{c}\text { Final } \\
\text { volume }(\boldsymbol{\mu l})\end{array}$ \\
\hline Water & & & $\mathbf{9 . 8 5}$ \\
\hline PCR buffer & $10 \mathrm{X}$ & $1 \mathrm{X}$ & $\mathbf{2 . 5}$ \\
\hline $\mathrm{Cl}_{2} \mathrm{Mg}$ & $50 \mathrm{mM}$ & $3 \mathrm{mM}$ & $\mathbf{1 . 5}$ \\
\hline dNTPs & $10 \mathrm{mM}$ & $0.2 \mathrm{mM}$ & $\mathbf{0 . 5}$ \\
\hline Primer ITS1 & $50 \mu \mathrm{M}$ & $0.4 \mu \mathrm{M}$ & $\mathbf{0 . 2}$ \\
\hline Primer ITS 4 & $50 \mu \mathrm{M}$ & $0.4 \mu \mathrm{M}$ & $\mathbf{0 . 2}$ \\
\hline Taq-polimerase & $5 \mathrm{U} / \mu \mathrm{l}$ & 1.25 & $\mathbf{0 . 2 5}$ \\
\hline cADN & $\mathbf{1 0 ~ n g / \mu l}$ & & $\mathbf{1 0} \boldsymbol{\mu l}$ \\
\hline
\end{tabular}

Table 2: Protocolo de PCR para amplificación de la región ITS: cantidades y concentraciones de reactivos para un volumen de $25 \mathrm{ul}$.

variances was determined for each of the variables studied using the Fisher variances quotient test. The detection of outliers was performed by Grubbs test.

With respect to statistical inference, both parametric tests (Test $t$ for two independent samples) and non-parametric tests (Mann-Whitney $\mathrm{U}$ test) were used for independent variables; considering a value of $\mathrm{p}$ less than alpha error, assuming as alpha a value equal to $5 \%$.

\section{Evaluation of repeatability and reproducibility}

The precision of each system was determined by repeatability and reproducibility. Repeatability was evaluated by assaying 4 replications of the same sample or strain at the same time (day 1), calculating average, standard deviation and coefficient of variation. Reproducibility was determined by assaying 4 replications of the same sample or strain on a different day (day 2), calculating average, standard deviation and coefficient of variation of the 4 matrices and contrasting with day 1 results. Inter-operator variability was evaluated by independent analysis of 8 replications of the same sample or strain done on the same day by two different operators from the same laboratory (4+4). Average, standard deviation and coefficient of variation were calculated. This procedure was done for each kit or commercial system.

\section{Results and Discussion}

\section{Comparison of qiagen and zymo research systems}

Results for concentration and purity were compared. To detect differences between the means of RNA concentration obtained with both commercial systems, Student's t test was used for two independent samples, since both variables demonstrated normality and equality of variances and absence of outliers; hypothesizing that the difference between the means is not equal to. Figure 6 shows that RNA yield was significantly greater for the Zymo Research system than the Qiagen system ( $\mathrm{p}=0.00054)$. This difference was probably caused by 
the Zymo Research system's guanidine phenol-isothiocyanate-based compound used for homogenization, since the Zymo Research and Qiagen protocols are very similar. Indeed, a study by Sandoval et al. evaluating different methods (Trizol, $\mathrm{CTAB}+\mathrm{LiCl} 2$ and RNeasy Mini kit by Qiagen) for extraction of RNA from the native fungus Xylaria sp. found that the differences in RNA yield were mainly affected by the homogenization system and protocol used [15]. To date, no study on the subject or comparing two commercial systems has been published specifically for yeasts.

To detect differences between the means of the variables absorbance 260/280 and absorbance 260/230, the nonparametric test U de Mann de Whitney was used, since both variables showed lack of normality, lack of equality of variances, as well as presence outliers. Evaluation and comparison of the purity of the RNA product between the two commercial systems showed that the Qiagen system was better at obtaining a product with less protein contamination, whereas the Zymo Research system was better at obtaining an RNA product less contaminated with phenols and carbohydrates (Figure 7), both with statistically significant differences (Absorbance 260/280:p=0,0003/ Absorbance 260/230: $p=0,0117$ ).

No similar paper was found in scientific databases with which to contrast these results. However, studies on filamentous fungi report that the Qiagen RN easy mini kit system is less effective for obtaining RNA extracts with optimal 260/230 ratios. For example, Sandoval et al. obtained RNA with low 260/230 absorbance values $(<1.8)$ from extracts of the fungus Xylaria sp. using the Qiagen RNeasy mini kit [16]. This may be due to the absence of phenol in the RLT lysis buffer used by Qiagen, considering that Guzman et al. claim that one of the properties of phenol is to foster elimination of carbohydrates from samples [17]. In such regard, Dorrie et al. report that fungal RNA extracts often have a low A260/230 ratio due to contamination with melanin, which also absorbs light in the 200-400 nm spectrum [17].

Furthermore, Sánchez et al. claim that there may be contamination by presence of residual sugars at the end of the extraction when extraction kits are used because the carbohydrates in the sample may establish hydrophobic interactions with the matrix which has the oligo $\mathrm{dT}$ groups necessary to capture RNA polyA+ terminal sequences [18].

\section{Evaluation of RNA integrity}

The Zymo Research system provided lower-quality RNA, with $62.5 \%$ of the samples ( 5 samples out of 8 ) moderately degraded (Figure 8 ). The Qiagen system produced RNA with better integrity, with only $25 \%$ of the samples ( 2 out of 8 ) partially degraded (Figure 8 ). This is consistent with absorbance at $260 / 280$, which was significantly higher in the Qiagen system than in the Zymo-Research system.

No study was found in the literature with which to contrast our results regarding integrity. But according to the information obtained in the present study, yield and spectrophotometric values are not completely reliable parameters to define whether an RNA extract is good enough not to affect RT-PCR efficiency. Other researchers such as Sandoval et al. and Kasajima et al. agree with this suggested criterion $[15,19]$.

\section{Evaluation of the precision of the Qiagen extraction system}

Intra-day, inter-day and inter-operator variability were measured using the proposed method. Intra-day and inter-day variability were both 9\% (RSD). Intra-operator variability was $19.6 \%$ for all 3 parameters evaluated (yield, absorbance $260 / 280$ ratio and absorbance $260 / 230$ ratio).

\section{Evaluation of the precision of the Zymo research extraction system}

Intra-day, inter-day and inter-operator variability were measured using the proposed method. Intra-day and inter-day variability were $3 \%(\mathrm{RSD})$ and $5 \%(\mathrm{RSD})$, respectively. Intra-operator variability was $22.6 \%$ for all 3 parameters evaluated (yield, absorbance 260/280 ratio and absorbance $260 / 230$ ratio).

\section{Reference primer design for the nuclear ribosomal DNA ITS1-ITS2 region (internal transcribed spacer)}

This region was selected as a reference or housekeeping target because it is transcribable and present in all fungi, whether filamentous or yeast-shaped, in addition to being frequently used in phylogenetic and taxonomic studies [20].

Following the criteria of Sandoval-Pineda et al., and with the aim

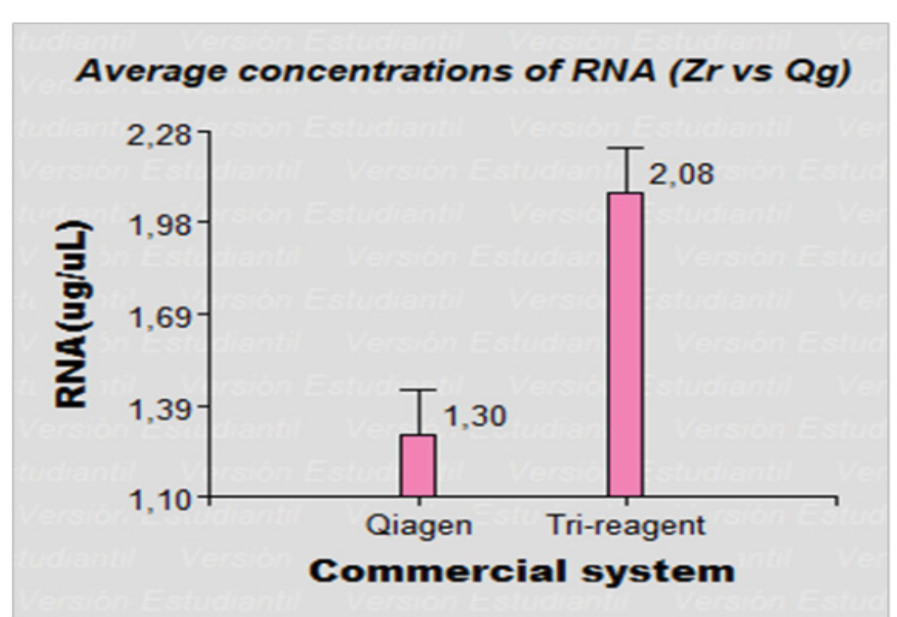

Figure 6: The Zymo research system using tri-reagent as a lysis buffer generated the highest values of RNA concentration, with a significant difference over the qiagen system.

Difference of means: $0.78 /$ IC95\%: 0.37-1.20/p-valor: 0.00054 . 
of predicting the efficiency of the primer before its in vitro validation in PCR reactions, the mFold software was used to determine the tendency of the primers to form secondary structures. It was found that optimal energy $(\Delta G)$ is -2.01 and $1.95 \mathrm{Kcal} / \mathrm{mol}$ for sense and antisense primers, respectively. This value refers to the minimum amount of energy required to break said structures. $\Delta \mathrm{G}$ values lower than $-9 \mathrm{Kcal} / \mathrm{mol}$ may cause problems in PCR reactions, usually associated to high GC content which would requiere aggressive denaturing conditions such as higher dissociation temperatures, causing rapid deterioration of the polymerase [15].

According to Dieffenbach et al., a pair of primers has low probability of forming secondary structures when Tm ranges from 50 to $60^{\circ} \mathrm{C}$; the difference of the Tm of the two sequences should not exceed $2^{\circ} \mathrm{C}$; and with autocomplementary values at the $5^{\prime}$ and $3^{\prime}$ ends of: $(\mathrm{ANY}<3$; and $\left.3^{\prime}<6\right)[21]$. However, the in silico analysis did not provide perfect values on primer thermodynamic characteristics, particularly for the forward primer. Nevertheless, the in vitro validation enabled us to confirm the usefulness of the pair of primers, since we were able to obtain the desired amplification product (Figure 9).

The ITS1 and ITS4 primers were validated and optimized by an annealing temperature gradient, where the optimum temperature was $55^{\circ} \mathrm{C}$, temperatures lower than $50^{\circ} \mathrm{C}$ favored non-specific amplifications and temperatures higher than $61^{\circ} \mathrm{C}$ inhibited primer hybridization (data not shown). A sensitivity test was used to determine that the pair of primers used has an amplification limit of up to $100 \mathrm{ng}$ of DNA (Figure 9). No study which would serve for discussion of this point was identified in the literature review, since most papers on gene expression use the beta-tubulin gene as reference gene.

\section{RT-PCR result}

RT-PCR provided the expected amplification product $(517 \mathrm{pb})$ in all samples evaluated (8 processed with Qiagen and 8 processed with Zymo-Research), and both cDNA dilutions (1:10 and 3:10) produced bands. This means that RNA purified with both systems had sufficient qualities to be amplified by PCR (Figure 9), despite contamination with proteins and carbohydrates and partial degradation in some samples, although the bands produced by RNA extracts obtained with Qiagen were sharper than those produced by RNA extracts obtained with the
Zymo Research system. Nonetheless, rRNA band intensity bought to be even for all samples regardless of the commercial system used, since the expression of that region should be consistent among all strains, as they all belong to the same species.

These results suggest that the RNA obtained using the Zymo Research protocol may have reduced the efficiency of the RT-PCR reaction. One of the causes may be the composition of the lysis buffer, considering that Sánchez et al. report that even after centrifugation, considerable amounts of lysis buffer may remain trapped within internal spaces of amorphous precipitated matter, possibly affecting the efficiency of the PCR reaction, ultimately producing tenuous bands in the electrophoresis gel [18-21].

Whatever extraction method is used to obtain nucleic acids from fungal cells, we believe it is important to highlight that fungi, like encapsulated and Gram-positive bacteria, pose a challenge for nucleic acid extraction methods. In true fungi such as yeasts and filamentous fungi, the main obstacle for any nucleic acid extraction method is undoubtedly the cell wall, which is a matrix made up of three main components: chitin (with greater presence in filamentous fungi than in yeasts), glucans and proteins [22]. Oomycetes and Myxogastria, which for a long time were considered part of the "fungus" kingdom, are currently considered pseudo-fungi because they have cell walls of similar composition, but structural and molecular evidence has reclassified them as heterokonts, related to autotrophic brown algae and diatoms. In contrast to fungi, Oomycetes typically have cell walls composed of cellulose and glucans instead of chitin [23]. It is very important to consider these cell wall features whenever an experiment is designed to extract nucleic acids from fungi or pseudo-fungi because, according to Francesconi et al., the different cell wall components have a significant effect on the quality of the DNA and RNA extracts, with dramatic impact on the outcomes of genetic studies [24].

Techniques for breaking down fungal cell walls include: (a) techniques based only on enzymatic methods (zymolyase or liticase), (b) techniques based on physical treatment by freezing with liquid nitrogen followed by grinding with mortar and pestle or shaking with beads, and (c) methods combining physical and enzymatic or physical and chemical treatments [25-30].

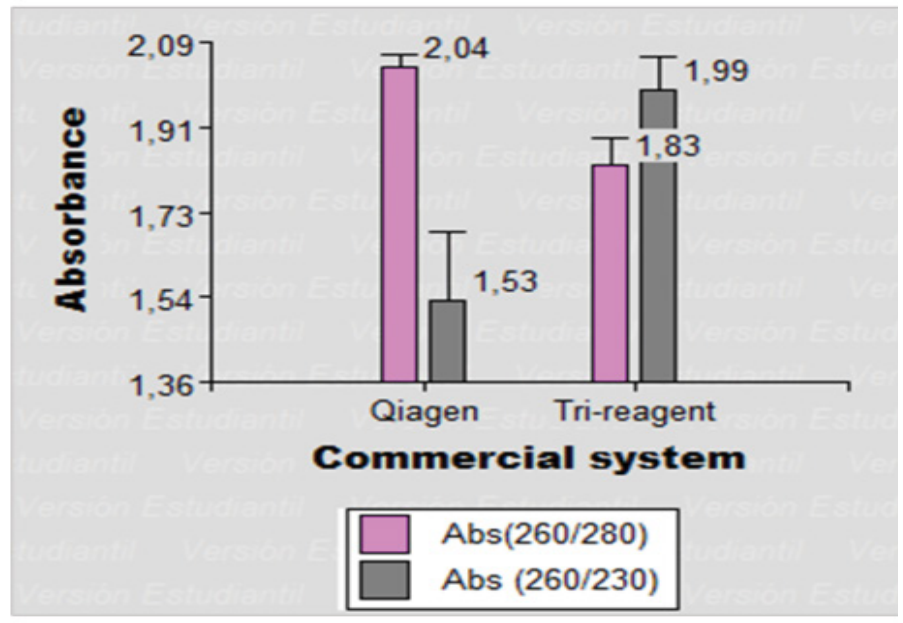

Figure 7: Average absorbance ratios $260 / 280$ and $260 / 230$ of both commercial systems.

Note: Qiagen: IC95\% of Absorbance (260/280): 1.99- 2.10/IC95\% of Absorbance (260-230): 1.23-1.84 Zymo-research: IC95\% of Absorbance (260/280): 1,711,95/IC95\% of Absorbance(260/230): 1.83-2.1 


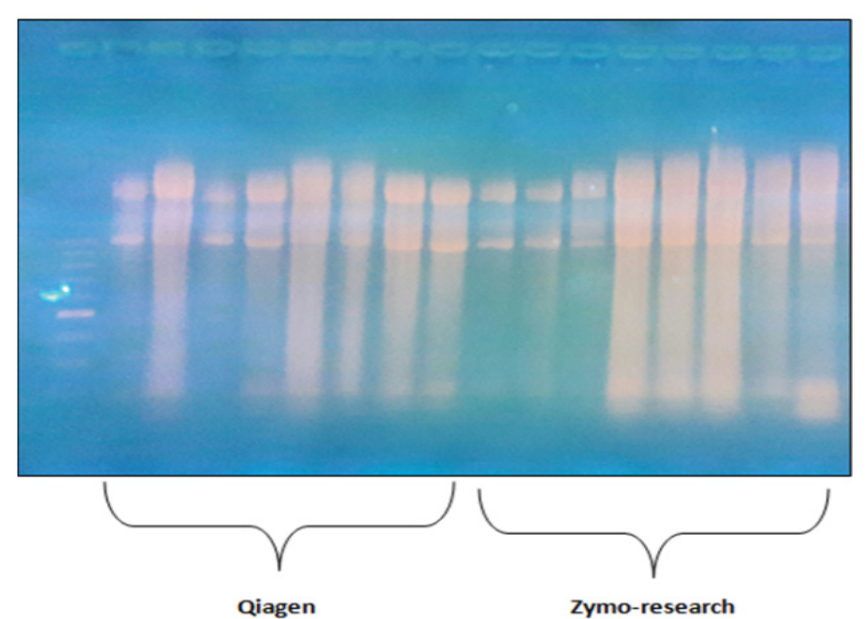

Figure 8: To evaluate the integrity of the extracted RNA, it was run on $2 \%$ agarose gel, 8 samples extracted with Qiagen system, and 8 samples extracted with Zymoresearch system, chosen at random.In each street 10uL of RNA was seeded with a concentration equivalent to 5ug of RNA. Note the absence in all lanes (2-17) of genomic DNA.

Calle 1: Ladder DNA

Street 2 to 9: RNA extracted and purified with Qiagen system

Calle 10 to 17: RNA extracted and purified with Zymo-research system

Streets $6,7,12,13,14,15,16$ with partial degradation.

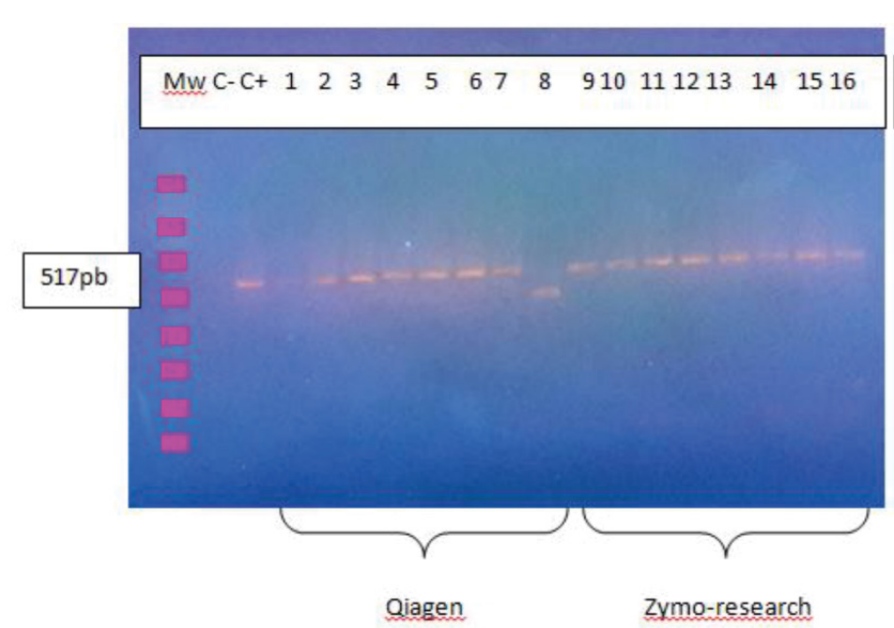

Figure 9: Electrophoretic run of PCR products:

WM= Ladder DNA 100pb. (The "ladder is over-drawn by low resolution of the reagent, because it was overdue).

$\mathrm{C}-=$ negative control;

$\mathrm{C}+=$ positive control, with genomic DNA (10uL/100ng) of reference strain (ATCC 22019)

$1=$ detection limit control with sample cDNA (1uL/1ug) 7334;

$2-8=$ cDNA of samples: 12A; 6912; 7066; 6PA; 6943; 75CA; 7.2 .

9-16= cDNA of samples: $5301 ; 46 \mathrm{~A} ; 16 \mathrm{~A} ; 53 \mathrm{~A} ; 11.1 ; 5462 ; 14.2 ; 15.1$

Note: Sample 8 throws a band of smaller size to the others. Probably it is a different genotype of the same species, since the strain is confirmed by sequencing that it is Candida parapsilosis sensu stricto.

The cell walls of yeasts have a lower percentage of chitin, enabling the use of lest strict methods for DNA and RNA extraction [22]. Yeast DNA extraction protocols published to date basically use physical treatments with glass beads combined with an enzymatic or chemical method $[29,30]$. However, extraction and purification techniques need to be adapted when the target is RNA, because it is unstable and more sensitive to endogenous and exogenous nuclease action (environment, operator). The only paper published using a yeast model to obtain RNA extracts is Mutio et al., which employs glass beads to break down the cell wall in presence of a buffer with guanidine to inhibit ribonucleases, complemented with acid phenol and silica columns to purify the target [31]. Said study reported excellent results for both yield and 260/280 absorbance ratio. Table 3 shows the advantages and disadvantages of the different lysis systems for RNA extracts which have been tested on yeasts and other types of fungi. Following Klassen et al., we used a spheroplast-forming solution based on sorbitol, phosphate buffer, 


\begin{tabular}{|c|c|c|c|}
\hline Lysis system & Mechanism of action & $\begin{array}{c}\text { Advantages for the target and } \\
\text { operator }\end{array}$ & $\begin{array}{c}\text { Disadvantages for the target and } \\
\text { operator }\end{array}$ \\
\hline $\begin{array}{l}\text { Zymolase } \\
\text { Querol et al. [25] } \\
\text { Klassen et al. [32] } \\
\text { Suzuki et al. [43] }\end{array}$ & $\begin{array}{l}\text { Enzymatic: Hydrolyzes glucose } \\
\text { polymers linked by } \beta-1,3 \text {-bonds, } \\
\text { producing laminaripentaose. }\end{array}$ & $\begin{array}{l}\text { High efficiency. No toxicity, and } \\
\text { avoid the use of phenol chloroform. } \\
\text { Does not affect the integrity of RNA. }\end{array}$ & $\begin{array}{c}\text { Consumption of time, high cost. } \\
\text { According to Suzuki et al., enzymatic } \\
\text { treatment can generate changes in } \\
\text { gene expression. However this has not } \\
\text { been validated. }\end{array}$ \\
\hline $\begin{array}{l}\text { Beta-Glucoronidase } \\
\text { Cadavid E et al. [42] }\end{array}$ & $\begin{array}{l}\text { Enzymatic: Catalyzes the reaction } \\
\text { Beta-D-glucuronoside }+\mathrm{H}_{2} \mathrm{O} \leftrightarrow \\
\text { D-glucuronate+ Alcohol }\end{array}$ & $\begin{array}{l}\text { Fast obtaining of DNA, in good } \\
\text { concentration and of high quality. } \\
\text { Decrease in time and costs. }\end{array}$ & There are no experiences with RNA. \\
\hline $\begin{array}{l}\text { Betamercaptoethanol } \\
\text { Nelson et al. [33] }\end{array}$ & $\begin{array}{l}\text { Chemical: Reducing agent, reduces } \\
\text { disulfide bridges. }\end{array}$ & $\begin{array}{l}\text { Irreversibly denatures } \\
\text { ribonucleases. Protects the RNA }\end{array}$ & $\begin{array}{l}\text { It's toxic for to the operator. Requires } \\
\text { combining with another method }\end{array}$ \\
\hline $\begin{array}{l}\text { SDS: Sodium Duodecyl Sulfate } \\
\text { Rojas et al. [34] } \\
\text { Rodrigues et al. [30] }\end{array}$ & $\begin{array}{c}\text { Chemical: lonic detergent, denatures } \\
\text { proteins. }\end{array}$ & $\begin{array}{l}\text { It does not affect the integrity of the } \\
\text { RNA. No toxicity and low cost. }\end{array}$ & $\begin{array}{l}\text { Contaminates the RNA with DNA. } \\
\text { Requires DNase purification. Inhibits } \\
\text { PCR at minimal concentrations. } \\
\text { Requires combining with another } \\
\text { method. }\end{array}$ \\
\hline $\begin{array}{c}\text { CTAB: Hexadecylmethylammonium bromide } \\
\text { Rodrigues et al. [30] } \\
\text { Sandoval et al. [15] }\end{array}$ & Chemical: Detergent. & $\begin{array}{l}\text { Reduce contamination with } \\
\text { carbohydrates. No toxicity. Low } \\
\text { cost. }\end{array}$ & $\begin{array}{l}\text { It does not protect the RNA from } \\
\text { degradation. Time consuming. It } \\
\text { requires combining with another } \\
\text { method. }\end{array}$ \\
\hline $\begin{array}{c}\text { Trizol/Tri-reagent } \\
\text { (Phenol, chloroform, more guanidine } \\
\text { isothiocyanate) Chomczynski [35] } \\
\text { Sandoval et al. [15] }\end{array}$ & $\begin{array}{c}\text { Chemical: Denatures and removes } \\
\text { proteins. }\end{array}$ & $\begin{array}{l}\text { It is an RNA stabilizer, Inhibits } \\
\text { RNases. Good quality and integrity } \\
\text { of RNA extracts have been reported } \\
\text { in Sacharomyces ceriviciae model }\end{array}$ & $\begin{array}{l}\text { It is toxic, requires cabin management } \\
\text { and protection barriers. It can generate } \\
\text { contamination with carbohydrates. It } \\
\text { decreases the performance of the PCR } \\
\text { at concentrations of } 0.2 \% \text { and } 0.5 \% \\
\text { completely inhibits it. High cost and } \\
\text { time consuming. Requires combining } \\
\text { with another method. }\end{array}$ \\
\hline $\begin{array}{c}\text { Glass beads } \\
\text { Hoffman y Winston [36] }\end{array}$ & $\begin{array}{c}\text { Mechanical: Breaks the cell wall by } \\
\text { hitting. }\end{array}$ & $\begin{array}{l}\text { No toxicity for the operator. Low } \\
\text { cost. }\end{array}$ & $\begin{array}{l}\text { It can compromise the integrity of } \\
\text { the RNA. Requires technique and } \\
\text { combination with another method. }\end{array}$ \\
\hline $\begin{array}{l}\text { Sonication } \\
\text { Muller et al. [29] }\end{array}$ & $\begin{array}{l}\text { Mechanical: Ultrasonic waves to stir } \\
\text { particles }\end{array}$ & $\begin{array}{l}\text { Suitable for all cell types and easily } \\
\text { applicable in small and large scale. } \\
\text { Save time. }\end{array}$ & $\begin{array}{l}\text { It requires optimization. It can degrade } \\
\text { the target molecule. Requires } \\
\text { combination with another method. High } \\
\text { price. }\end{array}$ \\
\hline
\end{tabular}

Table 3: Mechanism of action, advantages and disadvantages of the lysis systems most commonly used in fungi.

\begin{tabular}{|c|c|c|}
\hline & $\begin{array}{c}\text { Qiagen System } \\
\text { (RNeasy Mini Kit) }\end{array}$ & $1-2 \times 10^{7}$ \\
\hline Inoculum size & $\begin{array}{c}\text { Zymo-research system } \\
\text { (Drotein denaturation and } \\
\text { inhibition of RNasas }\end{array}$ & Isotiocianato of guanidina \\
\hline $\begin{array}{c}\text { Elimination of } \\
\text { carbohydrates }\end{array}$ & It is unknown \\
\hline Precipitation of RNA & Column \\
\hline Toxicity & Low \\
\hline Extracted material & Total RNA \\
\hline Prize in the Argentina for 50 columns & Coliocianato of guanidine + Phenol \\
\hline
\end{tabular}

Font: Hernández A et al. [37]

Table 4: Differences between Qiagen and Zymo-research system for RNA extraction and purification.

beta-mercaptoethanol and zymolyase to permeabilize the cell walls of the yeast Candida parapsilosis sensu stricto [32]. This choice was based on the good results obtained with zymolyase in nucleic acid extraction protocols in yeasts; and the fact that the addition of betamercaptoethanol to the solution potentiates the effect by protecting RNA from ribonuclease action due to its ability to eliminate disulfide bonds $[25,32,33]$.

The protocols developed and compared in this study offer both advantages and disadvantages, even though the Qiagen system has shown superiority in quality and integrity variables. The main difference between the two protocols is the lysis buffer composition, which in the Zymo-research system is a combination of acid phenol and guanidine, while Qiagen uses a lysis buffer without phenol and contains high concentrations of guanidine, providing an advantage from the standpoint of toxicity. Table 3 shows the main differences between the two extraction systems [34-37].

Los protocolos desarrollados y comparados en este estudio ofrecen tanto ventajas como desventajas, más allá de que el sistema de Qiagen haya demostrado superioridad en las variables de calidad e integridad. La principal diferencia en ambos protocolos se centra en la composición del buffer de lisis, siendo éste una combinación de fenol ácido y guanidina para el caso del sistema Zymo-research. Mientras que Qiagen emplea un buffer de lisis que carece de fenol y que contiene guanidina en altas concentraciones, lo cual es una ventaja desde el punto de vista de la toxicidad. En la tabla 6 se exponen las principales diferencias entre los dos sistemas de extracción (Table 4).

It is important to highlight the major progress achieved in recent years regarding nucleic acid extraction and purification. From 2009 
to 2011, the first papers were published reporting satisfactory results with the fluid/paper technology, showing that it is feasible to purify DNA based on filter paper chips [38,39]. In 2016, Rodriguez et al. published the first paper describing an improvement in the technique, using extraction, amplification and visual detection in addition to the paper/fluid technique for RNA. The study was designed with the aim of diagnosing Influenza $\mathrm{H} 1 \mathrm{~N} 1$ virus directly from clinical specimens. El It used an alternative Qiagen extraction method for extracting viral RNA (QIAamp Viral RNA Mini Kit) to contrast RNA yields, finding good correlation between quantities of RNA recovered by both methods. Detection sensitivity was lower in the paper-based RNA extraction method than in the standard qRT-PCR method, with a detection limit of $10^{6 \text { copies } / \mathrm{mL}}$ for the former and $10^{3 \mathrm{copies} / \mathrm{mL}}$ for the latter [40]. In 2017 a technical variation in the system was published. It applied nanotechnology to develop a chip that uses the paper/fluid technique to extract, amplify and detect optically (UV-LED light) the direct presence of miRNAs in animal cells, with the aim of enabling early diagnosis of cancers in which these small RNAs behave as biomarkers. The results were comparable to those using the qRT-PCR reference technique [4143]. Nevertheless, it should be noted that both of these papers use poor statistics to demonstrate their results.

To date, nothing has been published using the paper/fluid technology in the field of mycology. Although this new technology is time-saving and does not require centrifuges for the nucleic acid extraction step, it offers no benefit regarding toxicity, expense or the quantity of reagents and solutions needed, since it requires a lysis buffer to break down membranes, coprecipitants such as Glycoblue to increase pellet visibility, and toxic reagents such as chloroform and isopropyl alcohol, as well as the reagents required for the amplification and detection steps. We therefore consider that although paper/fluid is a promising innovative technique to speed up microbial and oncological identification or diagnostic results, there are also disadvantages which limit access to it.

\section{Conclusion}

According to our results and reports in the literature, we can say that RNA extract quality does not depend explicitly on its concentration or on its spectrophotometry values, and that is essential to check quality by electrophoretic run, even though the procedure is somewhat complex. In this context, the Qiagen RNeasy mini kit proved to be superior to the Zymo Research system, generating a better quality RNA product with less intra-operator variability. However, we also consider that the choice of extraction method and/or protocol should be subject to various considerations such as budget, organism, and in particular, aim of the experiment. If the aim is to detect a gene with infrequent expression and low abundance, the system of choice should be the one providing the highest quality standards. In the opposite situation, it is possible to be more flexible in the choice of the method for RNA extraction and purification. It should be borne in mind that in fungal cells, the presence of cell wall is a key factor, since it can impact both yield and the quality of RNA extracts. The choice should be based on the biological system, as well as on the target to be recovered. A standard criterion is that no single method is $100 \%$ effective, and a combination of techniques is always needed to increase efficiency in nucleic acid extraction protocols.

\section{References}

1. Vermeulen J, De Preter K, Lefever S, Nuytens J, De Vloed F, et al. (2011) Measurable impact of RNA quality on gene expression results from quantitative PCR. Nucleic Acids Res 39: e63.
2. Al-Samarrai T, Schmid J (2000) A simple method for extraction of fungal genomic DNA. Lett Appl Microbiol 30: 53-56.

3. Loeffler J, Hebart H, Cox P, Flues N, Schumacher U, et al. (2001) Nucleic acid sequence-based amplification of Aspergillus RNA in blood samples. J Clin Microbiol 39: 1626-1629.

4. Einsele H, Hebart H, Roller G, Löffler J, Rothenhofer I, et al. (1997) Detection and identification of fungal pathogens in blood by using molecular probes. $J$ Clin Microbiol 35: 1353-1360.

5. Rojas L, Portal O, Jiménez E (2011) Extracción de ARN total en plantas y hongos filamentosos. Biotecnología Vegetal 11: 213-222.

6. Mark AL, Andrea T, Philip E, Alexander BM, Tina S, et al. (2015) A modular method for the extraction of DNA and RNA, and the separation of DNA pools from diverse environmental sample types. Front Microbiol 6: 476.

7. Fleige S, Pfaffl M (2006) RNA integrity and the effect on the real-time qRT-PCR performance. Mol Aspects Med 27: 126-139.

8. Mahmoud AG, Richard JJ, Pranab KM, Fan C, Masoumeh S, et al. (2010) Characterization of the oral fungal microbiome (Mycobiome) in healthy individuals. PLoS Pathog 6: e1000713.

9. Peters BA, Wu J, Hayes RB, Ahn J (2017) The oral fungal mycobiome: Characteristics and relation to periodontitis in a pilot study. BMC Microbiol 17: 157

10. Marcio N, Flavio Q, Tito A, Iris N, Jorge C (2013) Epidemiology of candidemia in Latin America: A laboratory-based survey. PLoS One 8: e59373.

11. Tadec L, Talarmin JP, Gastinne T, Bretonnière C, Miegeville M, et al. (2016) Epidemiology, risk factor, species distribution, antifungal resistance and outcome of Candidemia at a single French hospital: A 7-year study. Mycoses 59: 296-303.

12. Tan T, Hsu L, Alejandria M (2016) Antifungal susceptibility of invasive Candida bloodstream isolates from the Asia-Pacific region. Med Mycol 54: 471-477.

13. Eliakim-Raz N, Babaoff R, Yahav D, Yanai S, Shaked H, et al. (2016) Epidemiology, microbiology, clinical characteristics, and outcomes of candidemia in internal medicine wards-a retrospective study. Int J Infect Dis 52: $49-54$.

14. Giuseppina C, Grazia L, Osvalda De G, Giovanna B, Osvaldo M, et al. (2017) Candidemia in the Neonatal Intensive Care Unit: A retrospective, observational survey and analysis of literatura data. Biomed Res Int 7901763.

15. Sandoval J, Ochoa F, Torres E (2017) Evaluation of different RNA extraction methods from the native fungus Xylaria sp. Rev Colomb Biotecnol 19: 42-54.

16. Guzmán M, Ruiz E, Arciniegas N (2006) Occurrence and variability of Potato yellow vein virus in three departments of Colombia. J Phytopathol 154: 748-750.

17. Dörrie J, Wellner V, Kämpgen E, Schuler G, Schaft N (2006) An improved method for RNA isolation and re-moval of melanin contamination from melanoma tissue: Implications for tumor antigen detection and amplifica-tion. $J$ Immunol Methods 313: 119-128.

18. Sánchez R, Portal O, Rojas LE, Ocaña B, Mendoza M, et al. (2008) An efficient method for the extraction of high-quality fungal total RNA to study the Mycosphaerella fijiensis-Musa spp. interac-tion. Mol Biotechnol 40: 299-305.

19. Kasajima, Ichiro S, Katsutomo T, Yuri T, Teruhiko (2013) Large-scale extraction of pure DNA from ma-ture leaves of Cyclamen persicum Mill and other recalci-trant plants with alkaline polyvinylpolypyrrolidone (PVPP). Scientia Horticulturae 164: 65-72.

20. Rodríguez J, Cuesta I, Gómez A, Manuel C. Pruebas moleculares en el diagnóstico micológico. Enferm Infecc Microbiol Clin Supl 13: 47-53.

21. Dieffenbach C, Lowe T, Dveksler G (1993) General concepts for PCR primer design. Genome Re-search 3: S30-S37.

22. Alexopoulos C, Mims C, Blackwell M (1996) Introducción a la Micología 4 687-688.

23. Fry W, Grünwald N (2010) Introducción a los Oomicetes.

24. Francesconi A, Kasai M, Harrington S (2008) Automated and manual methods of DNA extraction for Aspergillus fumigatus and Rhizopus oryzae analyzed by quantitative realtime PCR. J Clin Microbiol 46: 1978-1984.

25. Querol A, Barrio E (1992) A comparative study of different methods of yeast strain characterization. Sys Appl Microb 15: 439-446. 
Citation: Rodríguez ML, Rosa AC, Jewtuchowicz VM (2018) RNA Extraction from the Yeast Candida parapsilosis Sensu Stricto Using Two Commercial Methods Based on Purification by Silica Columns J Microb Biochem Technol 10: 96-105. doi: 10.4172/1948-5948.1000401

26. Al-Samarrai T, Schmid J (2000) A simple method for extraction of fungal genomic DNA. Lett Appl Microbiol 30: 53-56.

27. Abdel-Hadi A, Carter D, Magan N (2010) Temporal monitoring of the nor-1 (afID) gene of Aspergillus flavus in relation to aflatoxin B1 production during storage of peanuts under different water activity levels. J Appl Microbiol 109: 1914-1922.

28. De Boer R, Peters R, Gierveld S, Schuurman T, Kooistra-Smid M, et al. (2010) Improved detection of microbial DNA after bead-beating before DNA isolation. J Microbiol Methods 80: 209-211.

29. Frank-Michael CM, Katherine EW, Miki K, Andrea F, Stephen JC, et al. (1998) Rapid extraction of genomic dna from medically important yeasts and filamentous fungi by high-speed cell disruption. J Clin Microbiol 1998: 16251629.

30. Rodrigues P, Venancio A, Lima N (2017) Toxic reagents and expensive equipment: Are they really necessary for the extraction of good quality fungal DNA? Lett Appl Microbiol 66: 32-37.

31. Mutiu A, Brand C (2005) RNA isolation from yeast using silica matrices. $J$ Biomol Tech 16: 316-317.

32. Klassen R, Fricke J, Pfeiffer A, Meinhardt F (2008) A modified DNA isolation protocol for obtaining pure RT-PCR grade RNA. Biotechnol Lett 30: 1041-1044.

33. Nelson D, Lehninger A, Cox M (2005) Lehninger principles of biochemistry. Nueva York: W.H. Freeman.

34. Rojas L, Portal O, Jiménez E (2011) Extracción de ARN total en plantas y hongos filamentosos. Biotecnología Vegetal 11: 213-222.

35. Chomczynski P (1993)A reagent for the single-step simultaneous isolation of RNA DNA and proteins from cell and tissue samples. Biotechniques 15: 532-537.
36. Hoffman C, Winston F (1987) A ten-minute DNA preparation from yeas efficiently releases autonomous plasmids for transformation of Escherichia coli. Gene 57: 267-272.

37. Hernández A, Guzmán M (2013) Comparison of RNA isolation methods for potato yellow vein virus (PYVV) detection by RT-PCR in different organs of Solanum tuberosum Group Phureja. Rev Colomb Biotecnol 15: 71-81.

38. Jangam SR, Yamada DH, McFall SM, Kelso DM (2009) Rapid, point-of-care extraction of human immunodeficiency virus type 1 proviral DNA from whole blood for detection by real-time PCR. J Clin Microbiol 47: 2363-2368.

39. Govindarajan AV, Ramachandran S, Vigil GD, Yager P, Böhringer KF (2012) A low cost point-of-care viscous sample preparation device for molecular diagnosis in the developing world; an example of microfluidic origami. Lab Chip 12: 174.

40. Rodriguez NM, Linnes JC, Fan A, Ellenson CK, Pollock NR, et al. (2015) Ellenson† paper-based RNA extraction, in situ isothermal amplification, and lateral flow detection for low-cost, rapid diagnosis of Influenza A (H1N1) from clinical specimens. Anal Chem 87: 7872-7879.

41. Deng H, Zhou X, Liu Q, Li B, Liu H, et al. (2017) Paperfluidic chip device for small RNAs extraction, amplification and multiplexed analysis. ACS Appl Mater Interfaces 9: 41151-41158.

42. Cadavid E, Ramírez M, López W (2009) Standardising a simple protocol for extracting yeast from genomic DNA. Rev Colomb Biotecnol 11: 125-131.

43. Tadahiro S, Yumiko I (2013) RNA Preparation of Saccharomyces cerevisiae using the digestion method may give misleading results. Appl Biochem Biotechnol 169: 1620-1632. 